\title{
Gene discovery from Jatropha curcas by sequencing of ESTs from normalized and full-length enriched cDNA library from developing seeds
}

\author{
Purushothaman Natarajan, Deepa Kanagasabapathy, Gnanasekaran Gunadayalan, Jasintha Panchalingam, \\ Noopur shree, Priyanka Annabel Sugantham, Kavita Kumari Singh, Parani Madasamy*
}

\begin{abstract}
Background: Jatropha curcas L. is promoted as an important non-edible biodiesel crop worldwide. Jatropha oil, which is a triacylglycerol, can be directly blended with petro-diesel or transesterified with methanol and used as biodiesel. Genetic improvement in jatropha is needed to increase the seed yield, oil content, drought and pest resistance, and to modify oil composition so that it becomes a technically and economically preferred source for biodiesel production. However, genetic improvement efforts in jatropha could not take advantage of genetic engineering methods due to lack of cloned genes from this species. To overcome this hurdle, the current gene discovery project was initiated with an objective of isolating as many functional genes as possible from J. curcas by large scale sequencing of expressed sequence tags (ESTs).

Results: A normalized and full-length enriched cDNA library was constructed from developing seeds of J. curcas. The cDNA library contained about $1 \times 10^{6}$ clones and average insert size of the clones was $2.1 \mathrm{~kb}$. Totally 12,084 ESTs were sequenced to average high quality read length of $576 \mathrm{bp}$. Contig analysis revealed 2258 contigs and 4751 singletons. Contig size ranged from 2-23 and there were 7333 ESTs in the contigs. This resulted in 7009 unigenes which were annotated by BLASTX. It showed 3982 unigenes with significant similarity to known genes and 2836 unigenes with significant similarity to genes of unknown, hypothetical and putative proteins. The remaining 191 unigenes which did not show similarity with any genes in the public database may encode for unique genes. Functional classification revealed unigenes related to broad range of cellular, molecular and biological functions. Among the 7009 unigenes, 6233 unigenes were identified to be potential full-length genes.

Conclusions: The high quality normalized cDNA library was constructed from developing seeds of $J$. curcas for the first time and 7009 unigenes coding for diverse biological functions including oil biosynthesis were identified. These genes will serve as invaluable genetic resource for crop improvement in jatropha to make it an ideal and profitable crop for biodiesel production.
\end{abstract}

\section{Background}

Jatropha curcas L., one of the 175 species in genus Jatropha of the family Euphorbiaceae is a perennial small tree or large shrub native to tropical America and is distributed throughout the tropics and subtropics of Asia and Africa [1]. Recently, jatropha oil is promoted as alternative transport fuel which can be directly blended with petro-diesel or transesterified with

\footnotetext{
* Correspondence: hod.gn@ktr.srmuniv.ac.in

Genomics Laboratory, Department of Genetic Engineering, SRM University,
} Chennai, Tamil Nadu, 603203 India

(C) 2010 Natarajan et al; licensee BioMed Central Ltd. This is an Open Access article distributed under the terms of the Creative Commons Attribution License (http://creativecommons.org/licenses/by/2.0), which permits unrestricted use, distribution, and reproduction in any medium, provided the original work is properly cited. methanol and used as biodiesel. From a global food security point of view, jatropha being a non-edible crop which can be grown in areas not suitable for agriculture, is a preferred source for biodiesel feedstock as it does not compete with production of food crops. It reduces the dependence on fossil fuel which is often imported by using precious foreign currency. Its decentralized production will provide income for a large number of small and marginal farmers. Biodiesel is also less harmful to the environment in that its production and combustion reduces emission of greenhouse gases by $41 \%$ relative to fossil fuel [2]. It is reported that biodiesel 
emits less particulate matter than diesel upon combustion [3]. In fact, large scale jatropha cultivation will improve the environment by greening the area and transforming the wasteland to productive land by preventing soil erosion, causing accumulation of organic matter, increasing soil microbial activity, etc.

The demand for biodiesel production is very huge that it cannot be met from wild grown plants. Increasing the jatropha production requires both to bring more area under cultivation and to enhance productivity. Though jatropha can grow and survive in wasteland with less water, nutrient, and virtually no pest and disease management, productive growth and better yield under restrictive environmental conditions require the development of resilient genotypes. Genotypes with improved drought tolerance are preferred for plantations in marginal lands. Large scale plantations may bring in new challenges which need to be addressed. It was reported that $J$. curcas planted in continuous stretches as a monocrop were devastated by flower and seed feeding insects Scutellera nobilis and Pempelia morosalis [4]. This indicates that plant breeding programs to develop pest and disease resistance are required when large scale cultivation of jatropha is planned.

In addition, jatropha oil composition itself may have to be modified to make it the best feedstock for biodiesel production. Oils with more of saturated fatty acids give higher cetane number, and oxidative stability which are desirable for combustion/ignition quality and shelf life of biodiesel, respectively. But jatropha oil contains less of saturated fatty acids (21.6\%) and more of unsaturated fatty acids $(78.4 \%)$ [5]. While viscosity of petrodiesel is $2.6 \mathrm{~mm}^{2} / \mathrm{s}$, it is $4.8 \mathrm{~mm}^{2} / \mathrm{s}$ for biodiesel derived from jatropha oil. Viscosity affects atomization of the fuel upon injection into the combustion chamber, and thereby, increases the formation of engine deposits [6]. More the carbon number of saturated fatty acids higher will be the viscosity. Jatropha contains $84.5 \%$ 18-carbon fatty acids and only $14.9 \% 16$-carbon fatty acids [5]. It is possible to make significant changes in the jatropha oil composition by genetic engineering of the metabolic pathway of oil biosynthesis. Therefore, there is a need and scope for genetic improvement of jatropha by using plant breeding and genetic engineering methods.

Genetic intervention in jatropha requires understanding of the biosynthetic pathways, metabolic flux control points, cloning of the genes that code for the enzymes and proteins involved in the metabolic pathways and development of molecular markers. Molecular studies in jatropha are limited and only a few genes have been isolated from jatropha $[7,8]$. Currently, the dbEST of NCBI contains only 250 annotated Expressed sequence tags (ESTs) from jatropha. We have initiated a gene discovery project by large scale sequencing of ESTs.
ESTs are short, single pass sequence reads from 5'or 3' end of randomly selected cDNA clones. Sequencing of ESTs has been successfully employed in several plants including tomato [9], citrus [10], castor [11], arabidopsis [12], rice [13], water melon [14], radish [15] with the objective of gene discovery, metabolic pathway interpretation, gene cloning, molecular marker development, construction of genetic and physical map and comparative mapping and analysis. When sequencing of ESTs is employed for gene discovery purpose, normalization of the cDNA library will greatly increase the efficiency and economy of the process. Normalization reduces the frequency of abundant genes (hundreds of mRNA copies per cell) and enriches the library with rare genes $(<10$ mRNA copies per cell) [16]. Since sequencing of ESTs is carried out with the ultimate objective of cloning the genes, it would be highly desirable to combine the normalization with enrichment for full-length clones. This paper reports construction of a normalized and full-length enriched cDNA library from developing seeds of $J$. curcas and isolation of 7009 unigenes by sequencing of 12,084 ESTs.

\section{Results and Discussion}

\section{Construction of CDNA Library}

Construction of cDNA library and sequencing of ESTs helps in rapid gene discovery especially in non-model organisms where no prior sequencing data is available. Next generation sequencing technologies can circumvent the need for constructing cDNA libraries and generate extraordinarily huge amount of sequencing data to further speed up the gene discovery process. However, sequencing of cDNA clones has several advantages over the next generation sequencing methods such as higher average read length, virtually no assembly problem, ability to isolate full length genes without going for RACE PCR and availability of physical clones for further characterization and applications.

For the present study, a normalized and full-length enriched cDNA library was constructed from developing seeds of $J$. curcas. The normalization efficiency was monitored by using chloramphenicol reporter gene. Before normalization, the reporter gene was added to the cDNA population to a redundant rate of about $1 \%$ which was found to be reduced to less than $0.025 \%$ after normalization. This indicated 40 fold reduction in abundance due to normalization. This normalization will greatly help to enrich the library for rare genes. In addition, it will increase the rate recovery of unigenes and reduce the cost of sequencing by avoiding redundant clones. In fact, the rate of recovery of unigenes in this study was about 58\% (7009 unigenes out of 12,084 ESTs) which is much higher than 30 to $40 \%$ reported from non-normalized cDNA libraries $[11,17,18]$. 
The cDNA library can be more efficiently used for gene discovery if normalization is combined with enrichment for full-length genes. This was done by removing cDNAs smaller than $0.5 \mathrm{~kb}$. Removal of smaller fragments will also increase the cloning efficiency of longer cDNAs. The cDNA library constructed for this study was estimated to contain about $1 \times 10^{6}$ clones. Ninety six clones were randomly selected to test for the enrichment of full-length genes in these clones. The insert size ranged between $0.8 \mathrm{~kb}$ and $3.2 \mathrm{~kb}$ with an estimated average insert size of $2.1 \mathrm{~kb}$ (Figure 1). BLASTX analysis of the sequences revealed that $94 \%$ of the clones could potentially encode for full-length genes. These results indicated that this cDNA library could be reliably used for the gene discovery project in jatropha.

\section{Sequencing of Expressed Sequence Tags (ESTs)}

From the normalized and full-length enriched cDNA library, 13,220 clones were patched for plasmid DNA isolation. Clones which did not grow in the selection medium or did not yield sufficient quantity or quality of plasmid DNA were discarded. Plasmid DNA suitable for sequencing was isolated from 12,810 clones. These clones were sequenced using M13 reverse primer (CAGGAAACAGCTATGAC) which directly reads the cDNAs from the 5 ' end. Nucleotide bases having Phred value less than 20 were discarded. Vector backbone and additional sequences that were added during cDNA

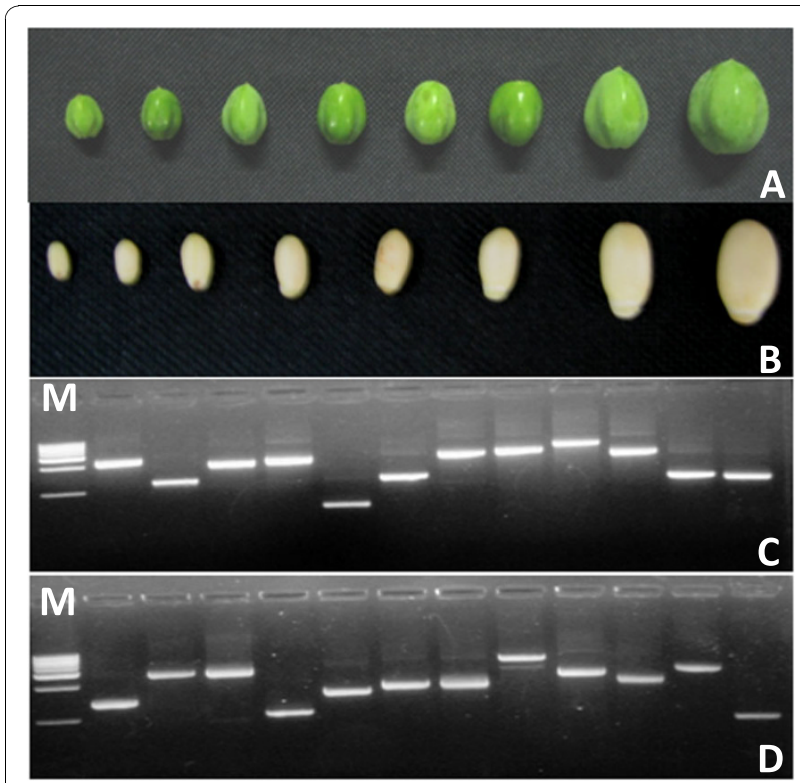

Figure 1 Construction of cDNA library from J. curcas. (A) Fruits of $J$. curcas in different sizes and green in colour (A) and the seeds were removed for total RNA isolation (B). Average insert size of the CDNA library was determined by colony PCR analysis of randomly selected clones(C \& D). 1.0 kb ladder DNA size markers (lane M) were used for size determination. synthesis were removed. After the trimming exercise 144 empty clones (resulted in 0 bases after trimming) and 12,084 high quality ESTs were obtained. The read length of the high quality ESTs ranged between $105 \mathrm{bp}$ and 874 bp with an average length of $576 \mathrm{bp}$ which is comparable with other reports $[19,20,18]$.

\section{Contig Assembly of ESTs}

Contig assembly of the 12, 084 ESTs was done to remove the redundant ESTs so that the unique ESTs (unigenes) can be annotated. The summary of the contig assembly is given in Table 1 . It showed 2258 contigs and 4751 singletons. The contig size ranged between 2 and 23 (Figure 2) and there were 7333 ESTs in the 2258 contigs indicating the presence of 5075 redundant ESTs. The 2258 contigs were manually checked and the longest EST from each contig was selected as unigene. These representative ESTs from contigs and the 4751 singletons together resulted in 7009 unigenes from the 12,084 ESTs assembled.

Sequencing of ESTs from developing seeds often showed the abundance of genes coding for seed storage proteins $[11,21,22]$. On the contrary, the current study the showed the abundance of genes related to stress response, disease resistance and plant development (Table 2). The largest contig contained 23 ESTs coding for phosphoethanolamine $\mathrm{N}$-methyltransferase which is essential for phosphatidylcholine biosynthesis. It is reported that $60.5 \%$ phospholipid in jatropha seed is composed of phosphatidylcholine [23]. Phosphatidylcholine is hydrolyzed into phosphatidic acid and choline. Phosphatidic acid acts as second messenger in stress signaling, and choline is a precursor for glycine betaine synthesis. Glycine betaine is a compatible solute and its accumulation is widely reported to confer salt and oxidative stress $[24,25]$. Other contigs contained ESTs coding for indole-3 acetic acid amido synthetase, ccr4 associated factor, ethylene responsive transcription factor and calcineurin $\mathrm{B}$ which are also involved in biotic and abiotic stress responses in plants [26-29]. The contigs also represented ESTs coding for protein disulfide isomerase, copine and sucrose synthase which are involved in seed development $[30,31]$ and seed size [32].

Table 1 Summary of Contig assembly

\begin{tabular}{lll}
\hline Description & Number & Percentage \\
\hline Total number of ESTs assembled & 12084 & - \\
Number of contigs & 2258 & - \\
Number of ESTs in contigs & 7333 & 60.6 \\
No. of ETS as singletons & 4751 & 39.3 \\
Number of unique ESTs (unigenes) & 7009 & 58.0 \\
\hline
\end{tabular}




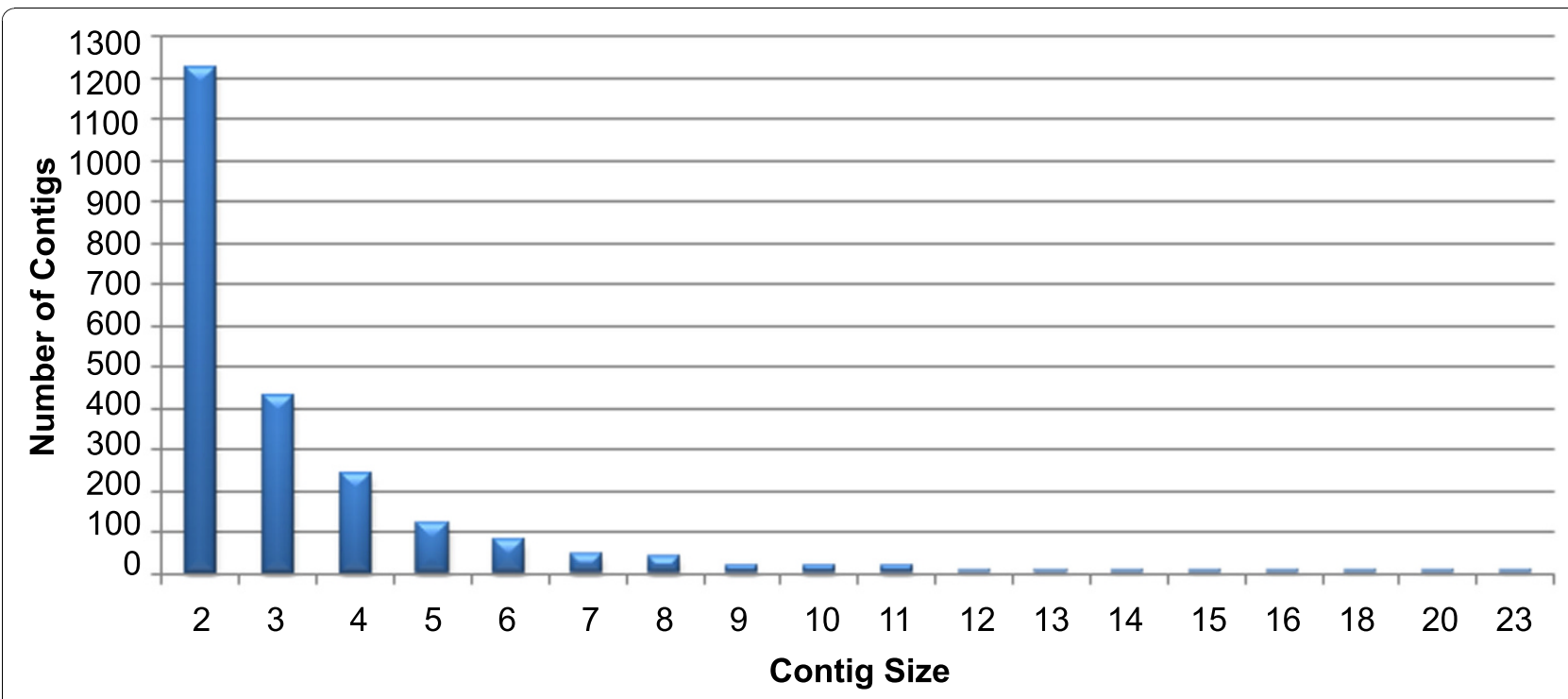

Figure 2 Distributions of ESTs in Contigs. Assembly of 12,084 ESTs resulted in 2258 contigs comprising 7333 ESTs. The distribution of 7333 ESTs in each contig was ranged between 2 and 23. The contig size represents the number of ESTs in the contig.

\section{Annotation of Unigenes}

In total, 3982 unigenes (56.8\%) showing significant similarity with genes available in the non-redundant database were identified. Most of these unigenes showed highest similarity with genes from castor (Ricinus communis). This is expected because jatropha itself is called 'wild' castor and both species belong to the family Euphorbiaceae. Next to castor, most of the unigenes showed similarity with genes from grape (Vitis vinifera) that belongs to the family Vitaceae. Phylogenetic analysis using 10 selected ESTs by including orthologs from five oilseed crops and $V$. vinifera also revealed that $J$. curcas is closely related to R. communis followed by $V$. vinifera (Figure 3, data shown for 3 genes). This association is totally unexpected according to the morphological system of classification [33] in which Jatropha belongs to monochlamideae whereas Vitis belongs to polypetalae. However, more recent Angiosperm Phylogeny Group Classifications, APGII and APGIII [34,35], which are based on cladistic analysis of larger data sets involving DNA sequences or other forms of systematic data show many contradictory relationships [36]. According to these classifications, the malpighiales (Euphorbiaceae) and Vitales (Vitaceae) are placed much closer under a major core eudicots clade, Rosids. Our data based on coding genes corroborate the APG classification with regard to Jatropha and Vitis.

\section{Genes for oil biosynthesis and $\beta$-oxidation}

Recently jatropha seed oil is widely used for biodiesel production as an alternative renewable energy source. It is important to undertake genetic improvement of this crop to increase oil content, to modify the oil composition, to remove toxic compounds, to increase drought tolerance etc. Seed oil content in brassica and arabidopsis has been increased by the overexpression of diacyl glycerol acyl transferase, lysophosphatidic acid acyltransferase, and glycerol-3-phosphate acyltransferase [37-39]. Seed oil composition has been changed in soybean by using mutant 3-Keto-acyl-ACP synthase II gene which increases the 16-carbon fatty acids and decreases 18 carbon fatty acids [40]. Silencing of stearoyl-ACP desaturase has dramatically increased the content of saturated fatty acid (stearic acid) from $1.2 \%$ to $32 \%$ in brassica [41]. Therefore, it is possible that increased oil content and specialized seed oil composition can be achieved in jatropha also, provided the genes involved in rate limiting steps of oil biosynthesis pathway are cloned. Important oil biosynthesis genes identified in the present study include the genes involved in fatty acid biosynthesis in plastids (carboxyl transferase of ACCase $\beta$ subunit, biotin carboxyl carrier protein of ACCase, malonyl-CoA:ACP transacylase, 3-keto acyl ACP reductase, beta-keto acyl ACP synthase I, betaketo acyl ACP synthase II and acyl carrier protein), desaturation of fatty acids ( $\omega$-3-fatty acid desaturase and $\omega$-6-fatty acid desaturase), hydrolysis of fatty acids from acyl-ACP (acyl ACP thioesterase A), activation and transport of free fatty acids to endoplasmic reticulum (long chain acyl-CoA synthetase, acyl -CoA binding protein) and serial incorporation of activated fatty acids to the glycerol backbone to form triacylglycerol or oil (glycerol-3-phosphate acyl transferase, lysophosphatidic acid acyl transferase). Some of these genes are being 
Table 2 List of abundant ESTs from the normalized cDNA library of Jatropha curcas L

\begin{tabular}{|c|c|c|c|}
\hline Contig ID & No. of ESTs & Annotation & Percentage* $^{*}$ \\
\hline Contig 1 & 23 & Phosphoethanolamine N-methyltransferase & 0.33 \\
\hline Contig 2 & 20 & Conserved hypothetical protein & 0.28 \\
\hline Contig 3 & 20 & Phosphoric diester hydrolase & 0.28 \\
\hline Contig 4 & 18 & Disease resistance protein RPM1 & 0.26 \\
\hline Contig 5 & 18 & Protein disulfide isomerase & 0.26 \\
\hline Contig 6 & 18 & Indole-3-acetic acid-amido synthetase GH3.3 & 0.26 \\
\hline Contig 7 & 18 & Hypothetical protein & 0.26 \\
\hline Contig 8 & 16 & Hypothetical protein & 0.23 \\
\hline Contig 9 & 16 & Receptor protein kinase & 0.23 \\
\hline Contig 10 & 16 & Branched-chain amino acid aminotransferase & 0.23 \\
\hline Contig 11 & 15 & Copine & 0.21 \\
\hline Contig 12 & 15 & 5-AMP-activated protein kinase & 0.21 \\
\hline Contig 13 & 15 & ATP binding protein & 0.21 \\
\hline Contig 14 & 15 & Vacuolar $\mathrm{Ca} 2+/ \mathrm{H}+$ exchanger & 0.21 \\
\hline Contig 15 & 14 & AMSH & 0.20 \\
\hline Contig 16 & 14 & UDP-glucosyltransferase & 0.20 \\
\hline Contig 17 & 14 & UDP-glucuronate 5-epimerase & 0.20 \\
\hline Contig 18 & 14 & ccr4-associated factor & 0.20 \\
\hline Contig 19 & 14 & Conserved hypothetical protein & 0.20 \\
\hline Contig 20 & 13 & 5-methyltetrahydropteroyltriglutamate-homocysteine S-methyltransferase & 0.19 \\
\hline Contig 21 & 13 & RNA recognition motif (RRM)-containing protein & 0.19 \\
\hline Contig 22 & 13 & Serine/threonine-protein kinase ASK1 & 0.19 \\
\hline Contig 23 & 13 & SEC14 cytosolic factor family protein & 0.19 \\
\hline Contig 24 & 13 & Conserved hypothetical protein & 0.19 \\
\hline Contig 25 & 13 & Threonyl-tRNA synthetase & 0.19 \\
\hline Contig 26 & 12 & Sugar transporter & 0.17 \\
\hline Contig 27 & 12 & ARMADILLO REPEAT ONLY 1(ARO1) & 0.17 \\
\hline Contig 28 & 12 & Cytochrome P450 & 0.17 \\
\hline Contig 29 & 11 & DELLA protein & 0.16 \\
\hline Contig 30 & 11 & Sucrose synthase & 0.16 \\
\hline Contig 31 & 11 & Transferase & 0.16 \\
\hline Contig 32 & 11 & Bifunctional dihydrofolate reductase-thymidylate synthase & 0.16 \\
\hline Contig 33 & 11 & Ethylene-responsive transcription factor & 0.16 \\
\hline Contig 34 & 11 & Calcineurin B & 0.16 \\
\hline Contig 35 & 11 & Beta-alanine-pyruvate aminotransferase & 0.16 \\
\hline Contig 36 & 11 & Poly(A)-binding protein & 0.16 \\
\hline Contig 37 & 11 & Metallothionein & 0.16 \\
\hline
\end{tabular}

* calculated as percentage of 7009 unigenes.

cloned in plant expression vector for functional evaluation in arabidopsis and tobacco. The unigene collection also contained genes for acyl-CoA oxidase, enoyl-CoA hydratase, $\beta$-hydroxyl acyl-CoA dehydrogenase and acyl-CoA acetyl transferase which are involved in $\beta$-oxidation of fatty acids and their derivatives. Many of the mutant studies revealed the importance of these enzymes in the breakdown of reserve triacylglycerol, seed development, seed germination, vegetative and reproductive growth phases [42]. Hence the cloning of the genes for beta oxidation pathway will be a valuable source for the genetic manipulation of oil degradation and plant growth.

\section{Genes for crop improvement}

Jatropha is a non-edible plant proposed to be grown in areas not suitable for agriculture such as wasteland, sides of railway track, lands with severe water scarcity, saline areas etc. Hence jatropha should be able to withstand these stresses. Plants respond to these stresses by modulating gene expression, which restores the cellular homeostasis, detoxification and recovery of growth $[43,44]$. For example, overexpression of betaine aldehyde dehydrogenase gene conferred salt stress tolerance in carrot, maize and tomato [45-47] and Zhang et al. [48] showed that glycine betaine level is increased under drought, heat and salt stresses in jatropha also. 

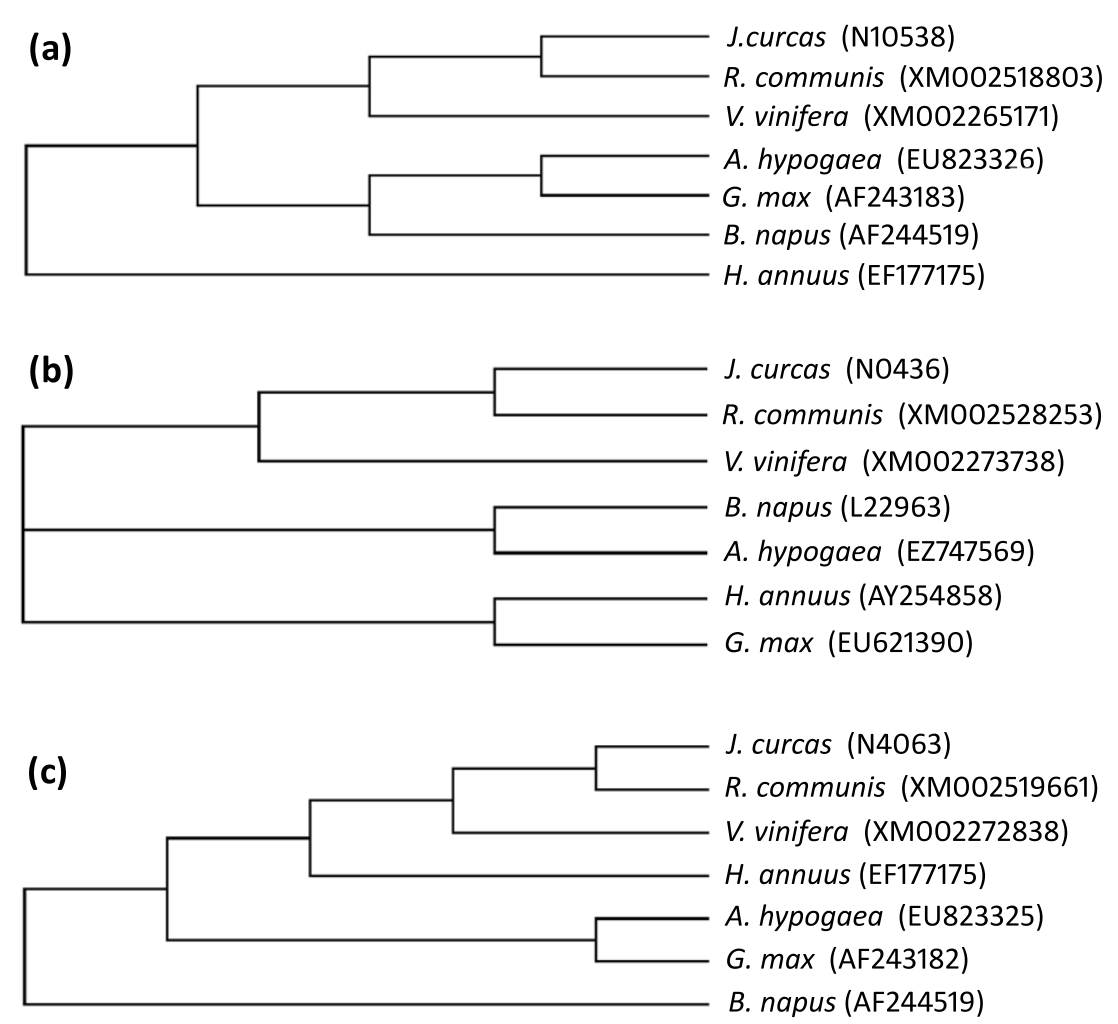

Figure 3 Phylogenetic analysis. Phylogenetic trees were generated using the DNA sequences coding for (a) beta-keto acyl ACP synthase II, (b) omega-3-fatty acid desaturase, and (c) beta-keto acyl ACP synthase I from J. curcas, R. communis, G.max, A. hypogaea, B. napus, H. annuus and V. vinifera. Clone IDs (for J. curcas) and Genbank accession numbers were given in the parentheses.

When enzymes for glycine betaine biosynthesis are expressed in plants that do not naturally produce glycine betaine, they accumulate little glycine betaine, because their endogenous choline supply is inadequate [49,50]. These plants may require overexpression of phosphoethanolamine $\mathrm{N}$-methyltransferase to overproduce choline. Overexpression of $\mathrm{Na}+\mathrm{H}+$ antiporter from Pennisetum glaucum conferred high level of salinity tolerance in transgenic Brassica [51] and overexpression of $E$. coli trehalose-6-phosphate synthase gene conferred drought and salt tolerance in rice [52]. The stress related unigenes identified in the current study include the genes coding for phosphoethanolamine $\mathrm{N}$-methyltransferase, $\mathrm{Na}+/ \mathrm{H}+$ antiporter, trehalose-6-phosphate synthase, glutathione peroxidase, glutathione s-transferase, spermidine synthase, ethylene-responsive transcription factors, ascorbate peroxidase, late embryogenesis abundant proteins, aquaporin, and salt tolerance protein.

The genes that code for the enzymes involved in different metabolic pathways are very important for genetic manipulation in jatropha. Several genes involved in diverse metabolic pathways such as phospholipids biosynthesis, flavanol synthesis, glycolysis, TCA cycle, HMP shunt, glycogenesis were identified from the current study. Other important genes identified from this study are ferritin, mevalonate kinase, lipoxygenase, glutamate decarboxylase, ent-kaurenoic acid oxidase, cinnamoylCoA reductase, zeta-carotene desaturase, gibberellin 2-oxidase, lipoic acid synthetase and beta-carotene hydroxylase. The unigenes also included 208 gene families with 3 or more genes. There were 15 families with more than 10 genes and a highest number of 46 members were identified in serine-threonine kinase gene family. Other gene families included glucan endo-1,3-beta-glucosidase precursor, aspartic proteinase nepenthesin-1 precursor, calmodulin binding protein, F-Box family protein, WDrepeat protein, pentatricopeptide repeat-containing protein, cytochrome $\mathrm{P} 450$ etc.

\section{Genes with unknown functions}

BLASTX results showed that $40.4 \%$ of $J$. curcas unigenes (2836) are having significant similarity with genes that code for unknown, hypothetical and putative proteins. This is significantly higher than 13 to $25 \%$ unknown genes reported in arabidopsis, citrus and oil palm $[12,53,54]$. It was found that $2.8 \%$ of $J$. curcas unigenes 
(191) did not have significant similarity with any genes available in the non-redundant database at NCBI. This is significantly lower than $8-24 \%$ of such genes reported in other plants $[55,12,56]$. These genes are very important as they may be specific to jatropha.

\section{Full-length unigenes}

Almost all of the unigenes will be full-length at the 3' end because first strand cDNA synthesis was carried out using oliog-dT(15) primer which initiates synthesis from poly (A) tail of the mRNAs. Therefore, full-length nature of the cDNAs at the 5 ' end was analyzed using the BLASTX results. This could be done for 6818 of the 7009 unigenes which showed significant similarity with genes in the non-redundant database at NCBI. It was found that $91.4 \%$ of the unigenes (6233) potentially code for full-length genes. This is significantly higher than $60-75 \%$ full-length genes reported before $[55,10,57]$. The remaining 191 unigenes that could not be analyzed by BLASTX for lack of similarity with genes in the database at NCBI were analyzed by predicting open reading frames (ORFs). In 14 unigenes, 5'UTR and single longest ORF covering almost the entire lengths of the sequences were identified (Figure 4). These unigenes could also be considered as potential full-length unigenes. In 18 unigenes, 5'UTRs were present but the ORFs terminated prematurely. We could not predict ORFs in the remaining 159 unigenes. These results show that the library is highly enriched with full length genes that it can be highly useful for gene discovery purpose.

\section{Functional Classification}

Functional coverage of the unigenes was identified by comparing the functional distribution of the genes from fully sequenced $A$. thaliana genome. Unigenes were searched against $A$. thaliana genome for functional annotation and locus identifiers using BLASTN at TAIR. The Gene Ontology annotations were assigned for each unigene based on the locus identifiers using GO annotation and categorization tool at TAIR. The 7009 unigenes from J. curcas were classified under three broad functional categories using GO slim terms. Distribution of $J$. curcas unigenes and A. thaliana genome under these three broad functional categories is shown in Figure 5. This classification provides information on percentage of $J$. curcas unigenes involved in the signal transduction, anabolism, catabolism, reproduction and so on. The results showed that the unigenes cover all the GO slim terms in Arabidopsis.

The unigenes were first classified according their function in 16 different cellular compartments and anatomical structures such as endoplasmic reticulum, plastid, mitochondria, nucleus, cell wall, golgi apparatus etc. which may have unique genes or specific expression profiles. The proportion of genes identified under each class was comparable with $A$. thaliana genome except those unigenes which were classified under 'unknown cellular components' (Figure 5A). Majority of the unigenes were grouped under 'other intra-cellular components', 'unknown cellular components', 'other cytoplasmic components' and 'chloroplast', which accounted for about $55 \%$ of the unigenes. Though, nongreen tissue was used for the cDNA library construction, about $12 \%$ of the unigenes belonged to chloroplast cellular component.

The unigenes were then classified according to their involvement in 14 different biological processes such as protein metabolism, developmental processes, response to stress, transcription, signal transduction etc. These processes are very important for a cell to live and reproduce. Hence, the genes that cover the biological processes are of great importance for functional study. It was found that the larger part of the J. curcas unigenes were grouped under 'other cellular process', 'other metabolic process' and 'unknown biological processes' accounting for $23.4 \%, 20.6 \%$ and $13.3 \%$, respectively (Figure 5B).

The unigenes were finally classified under 15 different molecular functions which mainly correspond to the activities performed by the gene products from individual gene or group of genes such as transferase activity, hydrolase activity, kinase activity, receptor binding, receptor activity etc. Greater part of the unigenes was classified under 'unknown molecular function', 'other enzyme activity', 'other binding', 'transferase activity' which accounted for $49.3 \%$ of the unigenes (Figure 5C).

\section{Validation of ESTs}

In order to validate the expression of ESTs, a set of 17 ESTs for representing oil biosynthesis genes were selected and their expression was studied in roots, mature leaves, flowers and developing seeds of $J$. curcas. These ESTs were first sequenced from the 3' ends and primers specific to 3'UTR were designed to increase their specificity to the respective transcripts. Gene expression was studied by using semi-quantitative RT-PCR and actin was used as an internal control (Figure 6). The results confirmed that the transcripts representing all the selected ESTs are actively expressed in J. curcas. All the transcripts were found to be expressed in all the tissues without significant variation in the level of expression, except ACP gene which showed significantly higher expression in flower. O'Hara et al. [58] have also reported that in flowers, the ACP gene is expressed at higher level than the other genes involved in fatty acid biosynthesis.

\section{Conclusions}

Normalized and full-length enriched cDNA library was constructed and 12,084 clones were sequenced from 


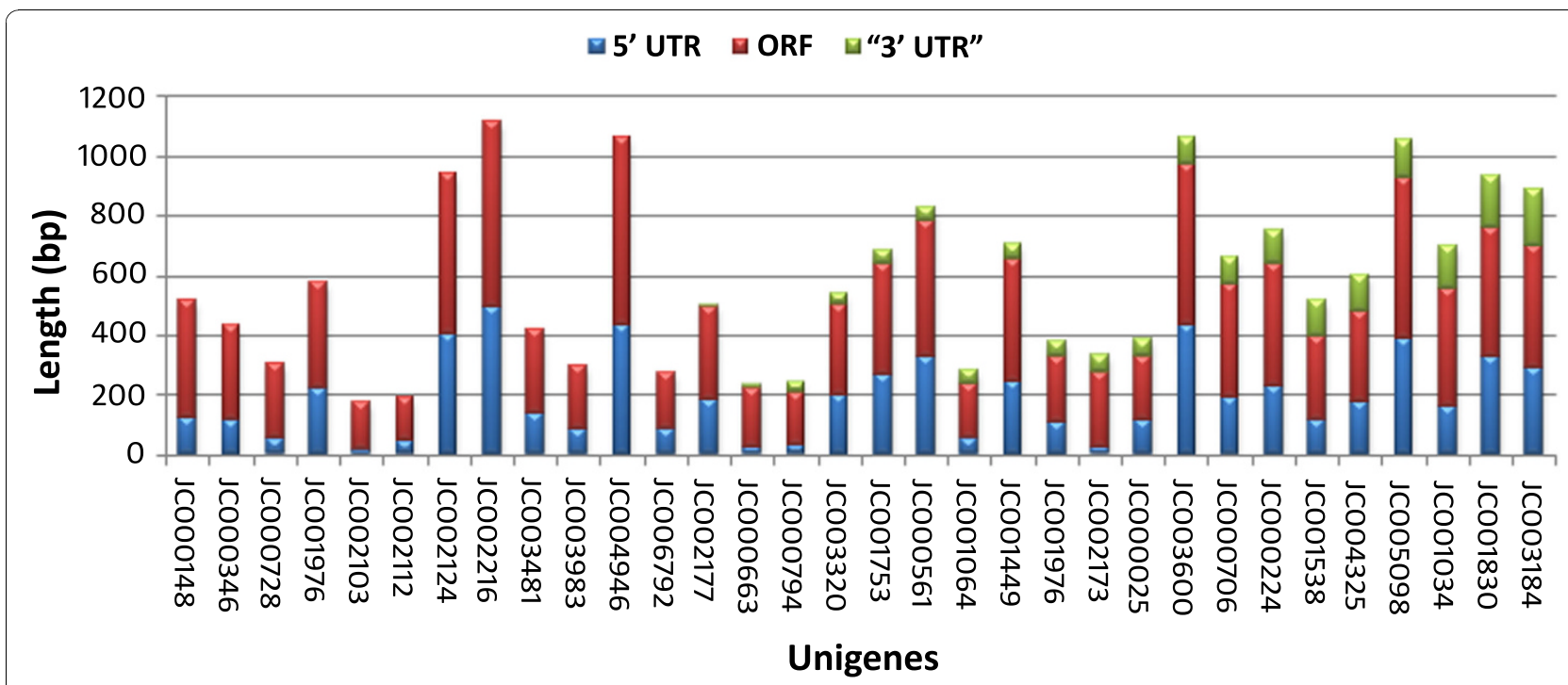

Figure 4 ORF analysis. The unigenes that did not show significant similarity to any genes in the protein database at NCBI were taken for ORF prediction using ORF finder tool at NCBI to identify potential full-length unigenes. Putative ORFs were predicted for 32 unigenes and 14 of them were found to be potential full-length unigenes.

J. curcas for the first time. From these sequences, 7009 unigenes were identified which included 6233 potential full-length genes. These genes encoded for diverse biological functions in J. curcas including oil biosynthesis, stress response, flavanol biosynthesis etc. These genes will serve as invaluable resource for the genetic engineering to modify oil composition and to increase oil content, seed yield, pest and disease resistance to make jatropha more suitable for biodiesel production and profitable to farmers. Gene discovery from other tissues of $J$. curcas are being attempted by using next generation sequencing technology.

\section{Methods}

\section{Collection of Seeds}

Seeds in different developmental stages were collected from Jatropha curcas fruits which were between 0.5 and $2.5 \mathrm{~cm}$ in diameter and green in colour (Figure 1). The seeds were flash frozen in liquid nitrogen and stored at $-86^{\circ} \mathrm{C}$ until further use.

\section{Isolation of Total RNA}

Total RNA from developing seeds was prepared using Trizol reagent following the manufacturer's protocol (Invitrogen, USA). One gram of the developing seeds were ground with liquid nitrogen to a fine powder and suspended in $10 \mathrm{ml}$ Trizol reagent. The suspension was mixed well, and incubated on ice for $10 \mathrm{~min}$. Subsequently, $2 \mathrm{ml}$ chloroform was added to the suspension and incubated on ice for $10 \mathrm{~min}$. The suspension was centrifuged at $10,000 \times \mathrm{g}$ for $15 \mathrm{~min}$ at $4^{\circ} \mathrm{C}$. The aqueous phase was transferred to a fresh tube, and equal volume of isopropanol was added. It was incubated at $-20^{\circ} \mathrm{C}$ for $1 \mathrm{~h}$, and total RNA was recovered by centrifugation at $10,000 \times \mathrm{g}$ for $20 \mathrm{~min}$ at $4{ }^{\circ} \mathrm{C}$. The supernatant was discarded and the pellet was washed with $70 \%$ ethanol, dried and dissolved in $200 \mu \mathrm{l}$ RNase free water. The total RNA was further purified by using RNeasy Mini Kit following the manufacturer's protocol (Qiagen, Hilden, Germany). Quality of total RNA was checked by agarose gel electrophoresis as well as $\mathrm{OD}_{260} / \mathrm{OD}_{280}$ ratio before using it for cDNA synthesis.

\section{cDNA Synthesis and Normalization}

Synthesis of full length cDNAs from total RNA and normalization were performed as described by Patanjali et al. [59] and Soares et al. [60] with slight modifications. Two cDNA preparations were made using the same total RNA. One was used as tester cDNA and the other was used as driver cDNA. First strand tester cDNA and driver cDNA were synthesized using tester3 primer (CAGTGGTATCAACGCAGAGTGGCCGAGGCGGCCT ${ }_{15}$ ) and driver3 primer (GGGATAACAGGGTAATGGCCGAGGCGGC CGACATGT $_{15}$ ), respectively. Tester adaptor (GTAACTAGGCCGTAATGGCCACTCTGCGTTGATACCAC TG) and driver adaptor (GGCCGTAATGGCCTCGCTACCTTAG GA) were ligated to the 3'end of the newly synthesised first strand tester cDNA and driver cDNA, respectively. These adaptors will ligate only to the 3 'end because, they were 5'phosphorylated and 3'blocked. Double strand tester cDNA was prepared by low cycling PCR using tester3 primer and phosphorylated tester5 primer (CAGTGGTATCAACGCAGAGTGGCCATTACGGCCTAGTTACGGG) which is complementary to the 5 'tester 


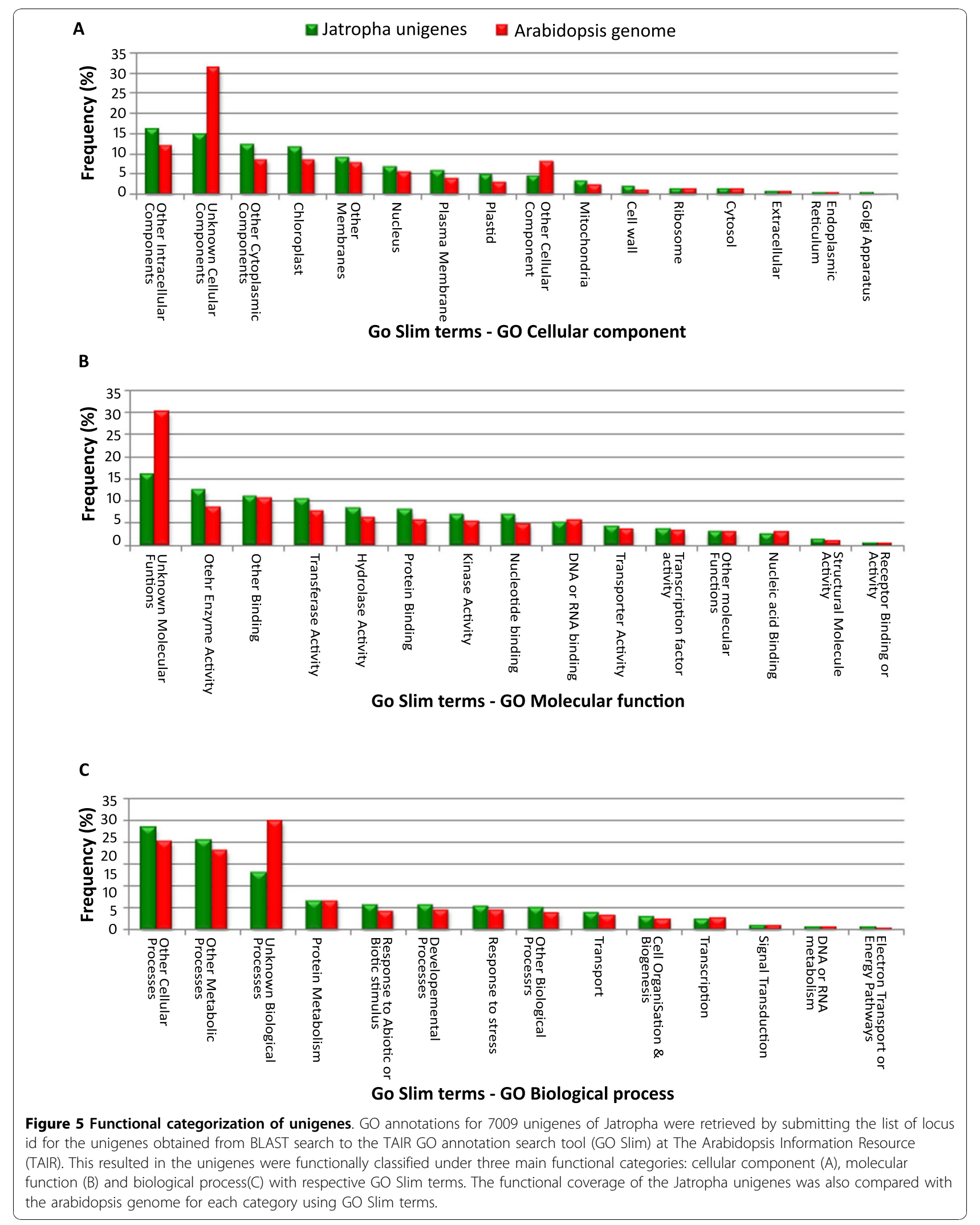




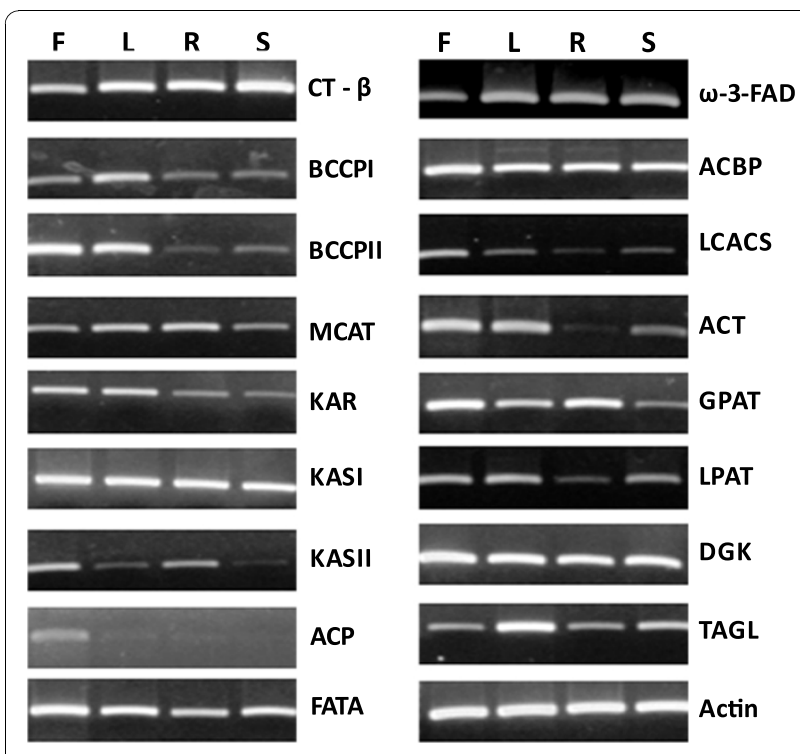

Figure 6 Semi-quantitative RT-PCR analysis of expression of selected genes. Expression of seventeen genes involved in oil biosynthesis were analysed by Semi-quantitative RT-PCR in flower (F), mature leaves $(\mathrm{L})$, root $(\mathrm{R})$, and developing seeds $(\mathrm{S})$ of J. curcas. Actin was used as an internal control. Name of the genes studied, the primers used for PCR amplification, and the size of the PCR amplified fragments are given in Table 3.

adaptor. The sense strand of the double strand tester cDNA which is phosphorylated at the 5'end was destroyed by treating it with lambda exonuclease. As a result only the anti-sense strands are retained. Double strand driver cDNA was prepared by low cycling PCR using phosphorylated driver3 primer and driver 5 primer (TCCTAA GGTAGCGAGGCCATTACGGCCGGG) which is complementary to the 5 driver adaptor. The anti-sense strand of the double strand driver cDNA which is phosphorylated at the 5 'end was destroyed by treating it with lambda exonuclease. As a result only the sense strands are retained.

Anti-sense strands from tester cDNA and sense strands from driver cDNA were mixed and hybridized in $1 \times$ hybridization buffer $(50 \mathrm{mM}$ Tris- $\mathrm{HCl} \mathrm{pH} \mathrm{8.0,0.5}$ $\mathrm{M} \mathrm{NaCl}, 0.2 \mathrm{mM}$ EDTA) at $68^{\circ} \mathrm{C}$ for $6 \mathrm{~h}$. The double strand hybrids formed during hybridization were removed by hydroxyapatite chromatography [59] for normalization of the single strand cDNA population. The normalized single strand cDNAs were converted to double strand cDNA and amplified by Failsafe ${ }^{\mathrm{TM}}$ PCR system (Epicentre Biotechnologies, USA) using amplification primer (CAGTGGTATCAACGCAGAGT) for which the binding sites are present both in the 5' and 3' end of the cDNA and it is specific to the tester cDNA only (underlined in tester 3 and tester 5 primers used for cDNA synthesis). The amplified cDNA was digested with $S f i$ restriction enzyme and cloned in modified pBluescript II SK${ }^{-}$in which SfiA (GGCCATTACGGCC) and SfiB (GGCCGAGGCGGCC) sites were introduced between EcoRI and XhoI. The ligated plasmids were transferred to E. coli $\mathrm{DH} 10 \mathrm{~B}-\mathrm{T} 1^{\mathrm{R}}$ (Invitrogen, USA) to construct the cDNA library.

\section{Normalization Efficiency}

Normalization efficiency was strictly monitored by performing parallel normalization experiment. Chloramphenicol resistance gene with same adaptor and primer sequences was used as reporter gene. In the parallel normalization, the reporter gene was added to the cDNA population as internal control at $1.0 \%$ redundant rate. Cloning of cDNA using modified pBluescript II $\mathrm{SK}^{-}$was performed. Normalization efficiency was determined by plating the cDNA library on LB plates containing chloramphenicol.

\section{Quality Control of cDNA Library}

Ninety six colonies from the cDNA library were randomly selected for quality control experiment. Cells from these 96 colonies were used for colony PCR as well as plasmid DNA isolation for sequencing. Colony PCR was performed using M13 forward (GTAAAACGACGGCCAGT) and M13 reverse primer (CAGGAAACAGCTATGAC). The PCR products were run on $1.0 \%$ agarose gel with $1.0 \mathrm{~kb}$ ladder as marker (Genie, Bangalore, India). Clones without cDNAs (empty clones) will give PCR product size of 226 bp and clones with cDNA will give variable PCR product size higher than $226 \mathrm{bp}$ depending on the length of the insert. Based on this, approximate size of cDNA in each clone was determined. For plasmid DNA isolation, the cells were inoculated in 5 $\mathrm{ml} \mathrm{LB}$ Broth supplemented with $50 \mathrm{mg} / \mathrm{L}$ ampicillin and incubated at $37^{\circ} \mathrm{C}$ at $200 \mathrm{rpm}$ for 16 hours. Plasmid DNA was isolated from $1.5 \mathrm{ml}$ of culture using Plasmid Miniprep Kit following manufacturer's protocol (Biobasic Inc, Canada). About $200 \mathrm{ng}$ of plasmid DNA was used for sequencing using M13 reverse primer and BigDye ${ }^{\mathrm{TM}}$ Terminator v3.1 Cycle Sequencing Kit in 3130xl Genetic Analyzer (Applied Biosystems, CA, USA). These sequences were annotated by using BLASTX algorithm and non-redundant database at NCBI [61].

\section{Sequencing of Expressed Sequence Tags (ESTs)}

The cDNA library was serially diluted and plated on Luria Bertani (LB) agar plates supplemented with $50 \mu \mathrm{g} / \mathrm{ml}$ ampicillin and incubated for 16 hours at $37^{\circ} \mathrm{C}$. Well separated single colonies were randomly selected and patched on LB agar plates supplemented with $50 \mu \mathrm{g} / \mathrm{ml}$ ampicillin, and incubated overnight at $37^{\circ} \mathrm{C}$. The cells from patched colonies were inoculated in $5 \mathrm{ml}$ LB Broth supplemented with $50 \mathrm{mg} / \mathrm{L}$ ampicillin and incubated at $37^{\circ} \mathrm{C}$ at $200 \mathrm{rpm}$ for 16 hours. Plasmid DNA was isolated from $1.5 \mathrm{ml}$ of culture using Plasmid Miniprep Kit following manufacturer's 
protocol (Biobasic Inc, Canada). Plasmid DNA was isolated from 12,810 cDNA clones. Sequencing of ESTs was performed using M13 reverse primer and BigDye ${ }^{\mathrm{TM}}$ Terminator v3.1 Cycle Sequencing Kit in 3130xl Genetic Analyzer (Applied Biosystems, CA, USA). The raw sequence data was base called by Phred program [62] using DNA Sequencing Analysis Software Version 5.1 (Applied Biosystems, CA, USA). Only the bases having Phred value above 20 were considered for further analysis. The vector sequences and cDNA anchor sequences were removed using Codon Code Aligner (Codon Code Corporation, MA, USA). The clones having less than 100 bp good quality sequences were also removed from the analysis.

\section{Contigs assembly}

Contig assembly of ESTs was done using CAP3 program [63] and Codon Code Aligner (Codon Code Corporation, MA, USA). The default parameters set by CAP3 was used to assemble the ESTs in to contigs and singletons. The number of ESTs in the contigs was used to find the redundancy rate of the ESTs in the library. After the assembly result, the outputs were manually checked and redundant clones were removed. The total numbers of unique ESTs (unigenes) were calculated by adding all singletons and one EST from each contig.

\section{Annotation of Unigenes}

The unigenes were annotated using BLASTX and nonredundant database at NCBI [61]. All the sequences which showed significant similarity $\left(\mathrm{e}\right.$-value $\left.<\mathrm{e}^{-10}\right)$ were assigned putative functions. Others were classified as unigenes with no significant similarity.

\section{Phylogenetic analysis}

Ten ESTs of J. curcas from the current study were selected and corresponding genes from five oilseed crops and Vitis vinifera were obtained from Genbank at NCBI. The Phylogenetic analysis was done using ClustalW2 program [64].

\section{Identification of full-length unigenes}

Full-length nature of the cDNAs at the 5'end was analyzed from BLASTX output. A unigene was considered as potential full-length gene if (1) there was a bonafide 5'UTR, (2) the first amino acid in one of the positive reading frames of query sequence matches with the first amino acid in subject sequence from the database and (3) the reading frame covers the entire length of the query sequence. The unigenes that did not show significant similarity were analyzed for Open Reading Frames (ORF) using ORF Finder at NCBI [65]. The unigenes were considered as potential full-length gene if there was a bonafide 5' UTR and the longest ORF covered almost the entire length of the sequence.

\section{Functional Classification of Unigenes}

The unigenes were annotated again using BLASTN and NT database of arabidopsis at The Arabidopsis Information Resource (TAIR) [66]. This resulted in locus identifier for each unigenes. These locus identifiers were

Table 3 Primers and PCR product size of the genes used for semi-quantitative RT-PCR analysis

\begin{tabular}{|c|c|c|c|c|}
\hline $\begin{array}{l}\text { S. } \\
\text { No. }\end{array}$ & Gene Name & Forward primer & Reverse primer & $\begin{array}{l}\text { Product size } \\
\text { (bp) }\end{array}$ \\
\hline 1. & Carboxyl transferase of ACCase $\beta$ subunit (CT- $\beta$ ) & GAATGAGTTACTTCAGCTTCAC & АATTCACССTTCTTTСTGTTGA & 307 \\
\hline 2. & Biotin carboxyl carrier protein I of ACCase (BCCPI) & GTCGGCTAATCTTAAAGCTATTC & TGTITATAGCTTCACTAGTGTAC & 258 \\
\hline 3. & $\begin{array}{l}\text { Biotin carboxyl carrier protein II of ACCase } \\
\text { (BCCPII) }\end{array}$ & GATGCTCTCATTGCAATTCTC & TAATGATAAATAACAATGAAGAAGG & 278 \\
\hline 4. & Malonyl-CoA:ACP transacylase (MCAT) & ACTTCTCCTGTTCAATGGGAA & TCTCTAGTACATGACGCTAATC & 314 \\
\hline 5. & 3-keto acyl ACP Reductase (KAR) & GTTATCTCTCCCGAAAGTGTA & CACAGTATCTGTCACCTITC & 306 \\
\hline 6. & Beta-keto acyl ACP synthase I (KASI) & GCATCTGGCTTGTCTCCAT & GCAGAAGAACACAATITGATAC & 402 \\
\hline 7. & Beta-keto acyl ACP synthase II (KASII) & TGTTCCCAATTTGAAGAAGCAG & AGGAACACCAAATCCAATCTTAT & 307 \\
\hline 8. & Acyl carrier Protein (ACP) & AAGATCAGTCTAGGAAATCCTTC & GCATAAATTAGGAAATITTAGAGTGT & 180 \\
\hline 9. & Acyl ACP thioesterase (FATA) & AATAATGTAGATTTCTTTATITGTGT & AGTAAACGTAAAACAATACAGTTGAT & 285 \\
\hline 10. & $\omega$-3-fatty acid Desaturase ( $\omega-3-F A D)$ & AAAGCTGCAAAATITITATCTGCA & СССТСТCAAATCCAATCCAA & 215 \\
\hline 11. & Acyl -CoA binding protein (ACBP) & TGAACATTCTATGCCGCTTG & GAGAAATAAGGGTCACCATTATC & 310 \\
\hline 12. & Long chain acyl-CoA synthetase (LCACS) & ATCCATAGCATITGGCTITCAAA & CGTGTAGAAGATGAATTGTATAAC & 326 \\
\hline 13. & Acyl-CoA thioesterase $(A C T)$ & ACTCATCTTAGCTITGTATGTTC & CCCATTTCAATCACCGTTC & 173 \\
\hline 14. & Glycerol-3-phosphate acyl transferase (GPAT) & GGGTAACGTGTTGGGATTG & CACAGAATCCAAATAATTCTACATTT & 200 \\
\hline 15. & Lysophosphatidic acid acyl transferase (LPAT) & TGGTGTATGTTTGTGCTTGG & CTGTACAAAATTGAATCAAGCTITT & 238 \\
\hline 16. & Diacyl glycerol kinase (DGK) & CGGCTATTCGGTTGGAAATAA & GATITIGATACAACAAATTACCAGT & 296 \\
\hline 17. & Triacyl glycerol lipase(TAGL) & CTGGAGACAAGACGAGAATAA & СTTCTATCATAATCAATTATTGTTCG & 310 \\
\hline 18. & Actin & CAAGTCATCACCATTGGAGCA & GCCTCTTAATTCGGCTIAACA & 590 \\
\hline
\end{tabular}


submitted for functional classification using GO annotation tool (GOSlim) at TAIR. Functional classification was done under three Gene Ontology categories viz., cellular component, molecular function and biological process. These three broad categories were further classified with different GO Slim terms.

\section{Semi-quantitative RT-PCR}

Seventeen ESTs for oil biosynthesis genes and one EST for actin gene were selected from the current study and sequenced from 3' ends. Using these 3' end sequences, primers were synthesized to amplify the 3' UTR excluding the poly-(A) tail for all the genes except actin. For actin, the primers were synthesised to amplify a $590 \mathrm{bp}$ fragment which included $392 \mathrm{bp}$ from the 3 ' end of the coding region and $198 \mathrm{bp}$ from the 3' UTR. The primer sequences and the size of the amplified fragments are given in Table 3. For RT-PCR, total RNA from roots, mature leaves, flowers and developing seeds were treated with DNase and purified using RNeasy Mini Kit following the manufacturer's protocol (Qiagen, Hilden, Germany). About $3.0 \mu \mathrm{g}$ of purified total RNA from each sample was used for first strand cDNA synthesis using 50 pmol oliog-dT(18) primer and 100 units of PrimeScript ${ }^{\mathrm{TM}}$ reverse transcriptase (Takara Bio Inc, Shiga, Japan). Equal quantity of first strand cDNA (from $25 \mathrm{ng}$ total RNA) was used for PCR. Semi-quantitative analysis of the PCR amplified fragments was done by agarose gel electrophoresis and ethidium bromide staining.

\section{Accession numbers}

J. curcas unigenes were submitted to the dbEST database of Genbank at NCBI with the accession numbers GW874611 to GW881590 and HO004465 to HO004493.

\section{Acknowledgements}

Financial support provided for this project by the Department of Biotechnology, Government of India (Sanction order BT/PR/8647/PBD/26/38/ 2007) and the 16-capillary automated DNA sequencing machine (Genetic Analyzer 3130xl, Applied Biosystems) provided by the SRM University are gratefully acknowledged

\section{Authors' contributions}

The study was conceived and directed by PM. RNA isolation, construction of normalized cDNA Library, plasmid DNA preparation, automated DNA sequencing, assembly, annotation, validation of ESTs and other bioinformatics analysis were directed by PM and carried out by PN. Transformation and patching clones were done by DK and PN. Plasmid DNA Isolation and annotation was assisted by GG, JP, NS, PAS, and KKS. PM and PN wrote the paper. All authors read and approved the final manuscript.

Received: 19 June 2010 Accepted: 27 October 2010

Published: 27 October 2010

\section{References}

1. Mabberley DJ: The Plant Book, A portable dictionary of vascular plants. Cambridge Cambridge University Press 2005
2. Hill J, Nelson E, Tilman D, Polasky S, Tiffany D: Environmental, economic, and energetic costs and benefits of biodiesel and ethanol biofuels. Proc Natl Acad Sci 2006, 103:11206-11210.

3. Yuan $Y$, Mei D, Wang Z, Zhang T: Combustion and emissions of the diesel engine using bio-diesel fuel. Front Mech Eng China 2008, 3:189-192.

4. Shanker C, Dhyani SK: Insect pests of Jatropha curcas L. and the potential for their management. Current Science 2006, 91:162-163.

5. Akbar E, Yaakob Z, Kamarudin SK, Ismail M, Salimon J: Characteristic and Composition of Jatropha Curcas Oil Seedfrom Malaysia and its Potential as Biodiesel Feedstock. European Journal of Scientific Research 2009, 29:396-403.

6. Knothe G: Dependence of biodiesel fuel properties on the structure of fatty acid alkyl esters. Fuel Processing Technology 2005, 86:1059-1070.

7. Xie WW, Gao S, Wang SH, Zhu JQ, Xu Y, Tang L, Chen F: Cloning and expression analysis of carboxyl transferase of acetyl-coA carboxylase from Jatropha curcas. Z Naturforsch C 2010, 65:103-108.

8. Wu PZ, Li J, Wei Q, Zeng L, Chen YP, Li MR, Jiang HW, Wu GJ: Cloning and functional characterization of an acyl-acyl carrier protein thioesterase (JcFATB1) from Jatropha curcas. Tree Physiology 2009, 29:1299-1305.

9. Aoki K, Yano K, Suzuki A, Kawamura S, Sakurai N, Suda K, Kurabayashi A, Suzuki T, Tsugane T, Watanabe M, Ooga K, Torii M, Narita T, Shin-I T, Kohara Y, Yamamoto N, Takahashi H, Watanabe Y, Egusa M, Kodama M, Ichinose Y, Kikuchi M, Fukushima S, Okabe A, Sato TAY, Yazawa K, Satoh S, Omura T, Ezura H, Shibata D: Large-scale analysis of full-length cDNAs from the tomato (Solanum lycopersicum) cultivar Micro-Tom, a reference system for the Solanaceae genomics. BMC Genomics 2010, 11:210.

10. Marques MC, Cantabrana HA, Forment J, Arribas R, Alamar S, Conejero V, Amador MAP: A new set of ESTs and CDNA clones from full-length and normalized libraries for gene discovery and functional characterization in citrus. BMC Genomics 2009, 10:428.

11. Lu C, Wallis JG, Browse J: An analysis of expressed sequence tags of developing castor endosperm using a full-length cDNA library. BMC Plant Biology 2007, 7:42.

12. White JA, Todd J, Newman T, Focks N, Girke T, llarduya OMD, Jaworski JG, Ohlrogge JB, Benning C: A New Set of Arabidopsis Expressed Sequence Tags from Developing Seeds. The Metabolic Pathway from Carbohydrates to Seed Oil. Plant Physiology 2000, 124:1582-1594.

13. Jantasuriyarat C, Gowda M, Haller K, Hatfield J, Lu G, Stahlberg E, Zhou B, Li H, Kim H, Yu Y, Dean RA, Wing RA, Soderlund C, Wang GL: Large-Scale Identification of Expressed Sequence Tags Involved in Rice and Rice Blast Fungus Interaction. Plant Physiology 2005, 138:105-115.

14. Kim J, Lun SH, Lee L, Kang HG, Gynheung : An Expressed Sequence Tags and mRNA Expression Levels of Tagged cDNAs from Watermelon Anthers and Developing Seeds. Journal of Plant Biology 2001, 44:172-177.

15. Moon YH, Chae S, Jung JY, An G: Expressed sequence tags of radish flower buds and characterization of a CONSTANS LIKE 1 gene. Mot Cells 1998, 4:452-458.

16. Carninci $P$, Shibata $Y$, Hayatsu $N$, Sugahara $Y$, Shibata $K$, Itoh M, Konno H, Okazaki $Y$, Muramatsu M, Hayashizaki $Y$ : Normalization and subtraction of cap-trapper-selected cDNAs to prepare full-length cDNA libraries for rapid discovery of new genes. Genome Res 2000, 10:1617-1630.

17. Sakurai T, Plata G, Zapata RF, Seki M, Salcedo A, Toyoda A, Ishiwata A, Tohme J, Sakaki Y, Shinozaki K, Ishitani M: Sequencing analysis of 20,000 full-length cDNA clones from cassava reveals lineage specific expansions in gene families related to stress response. BMC Plant Biology 2007, 7:66.

18. Crowhurst RN, Gleave AP, MacRae EA, Dwamena CA, Atkinson RG, Beuning LL, Bulley SM, Chagne D, Marsh KB, Matich AJ, Montefiori M, Newcomb RD, Schaffer RJ, Usadel B, Allan AC, Boldingh HL, Bowen JH, Davy MW, Eckloff R, Ferguson AR, Fraser LG, Gera E, Hellens RP, Janssen BJ, Klages K, Lo KR, MacDiarmid RM, Nain B, McNeilage MA, Rassam M, Richardson AC, Rikkerink EHA, Ross GS, Schröder R, Snowden KC, Souleyre EJF, Templeton MD, Walton EF, Wang D, Wang MY, Wang YY, Wood M, Wu R, Yauk YK, Laing WA: Analysis of expressed sequence tags from Actinidia :applications of a cross species EST database for gene discovery in the areas of flavor, health, color and ripening. $B M C$ Genomics 2008, 9:351.

19. Futamura N, Totoki Y, Toyoda A, Igasaki T, Nanjo T, Seki M, Sakaki Y, Mari A, Shinozaki K, Shinohara K: Characterization of expressed sequence tags from a full-length enriched cDNA library of Cryptomeria japonica male strobili. BMC Genomics 2008, 9:383. 
20. Umezawa T, Sakurai T, Totoki Y, Toyoda A, Seki M, Ishiwata A, Akiyama K, Kurotani A, Yoshida T, Mochida K, Kasuga M, Todaka D, Maruyama K, Nakashima K, Enju A, Mizukado S, Ahmed S, Yoshiwara K, Harada K, Tsubokura Y, Hayashi M, Sato S, Anai T, Ishimoto M, Funatsuki H, Teraishi M, Osaki M, Shinano T, Akashi R, Sakaki Y, Shinozaki KY, Shinozaki K: Sequencing and Analysis of Approximately 40000 Soybean CDNA Clones from a Full-Length-Enriched cDNA Library. DNA Research 2008, 15:333-346.

21. Naoumkina M, Jerez IT, Allen S, He J, Zhao PX, Dixon RA, May GD: Analysis of cDNA libraries from developing seeds of guar (Cyamopsis tetragonoloba (L.) Taub). BMC Plant Biology 2007, 7:62.

22. Clarke BC, Hobbs M, Skylas D, Appels R: Genes active in developing wheat endosperm. Funct Integr Genomics 2000, 1:44-55.

23. Rao KS, Chakrabarti PP, Rao VSK, Prasad RBN: Phospholipid Composition of Jatropha curcas Seed Lipids. J Am Oil Chem Soc 2009, 86:197-200.

24. Holmstrom KO, Somersalo S, Mandal A, Palva TE, Welin B: Improved tolerance to salinity and low temperature in transgenic tobacco producing glycine betaine. Journal of Experimental Botany 2000, 51:177-185.

25. Liang $C$, Zhang XY, Luo $Y$, Wang GP, Zou Q, Wang W: Overaccumulation of Glycine Betaine Alleviates the Negative Effects of Salt Stress in Wheat. Russian Journal of Plant Physiology 2009, 56:370-376.

26. Sarowar S, Oh HW, Cho HS, Baek KH, Seong ES, Joung YH, Cho GJ, Lee S, Choi D: Capsicum annuum CCR4-associated factor CaCAF1 is necessary for plant development and defence response. The Plant Journal 2007, 51:792-802.

27. Ding $X$, Cao Y, Huang L, Zhao J, Xu C, Li X, Wang S: Activation of the Indole-3-Acetic Acid-Amido Synthetase GH3-8 Suppresses Expansin Expression and Promotes Salicylate- and Jasmonate-Independent Basal Immunity in Rice. The Plant Cell 2008, 20:228-240.

28. Lorenzo O, Piqueras R, Sánchez-Serrano JJ, Solano R: ETHYLENE RESPONSE FACTOR 1 Integrates Signals from Ethylene and Jasmonate Pathways in Plant Defense. The Plant Cell 2002, 15:165-178.

29. Gu Z, Ma B, Jiang Y, Chen Z, Su X, Zhang H: Expression analysis of the calcineurin $B$-like gene family in rice (Oryza sativa L.) under environmental stresses. Gene 2008, 415:1-12.

30. Ondzighi CA, Christopher DA, Cho EJ, Chang SC, Staehelin LA: Arabidopsis Protein Disulfide Isomerase- 5 Inhibits Cysteine Proteases during Trafficking to Vacuoles before Programmed Cell Death of the Endothelium in Developing Seeds. The Plant Cell 2008, 20:2205-2220.

31. Damer CK, Bayeva M, Hahn ES, Rivera J, Socec Cl: Copine A, a calciumdependent membrane-binding protein, transiently localizes to the plasma membrane and intracellular vacuoles in Dictyostelium. BMC Cell Biology 2005, 6:46.

32. Turner NC, Furbank RT, Berger JD, Gremigni P, Abbo S, Leport L: Seed Size Is Associated with Sucrose Synthase Activity in Developing Cotyledons of Chickpea Crop. Science 2009, 49:621-627.

33. Bentham G, Hooker JD: Genera Plantarum. L. Reeve \& Co, London 1862

34. APG II: An update of the Angiosperm Phylogeny Group classification for the orders and families of flowering plants: APG II. Botanical Journal of the Linnean Society 2003, 141:399-436.

35. APG III: An update of the Angiosperm Phylogeny Group classification for the orders and families of flowering plants: APG III. Botanical Journal of the Linnean Society 2009, 161:105-121.

36. Angiosperm Phylogeny Website. [http://www.mobot.org/mobot/research/ apweb].

37. Sharma N, Anderson M, Kumar A, Zhang Y, Giblin EM, Abrams SR Zaharia LI, Taylor DC, Fobert PR: Transgenic increases in seed oil content are associated with the differential expression of novel Brassica -specific transcripts. BMC Genomics 2008, 9:619.

38. Maisonneuve S, Bessoule JJ, Lessire R, Delseny M, Roscoe TJ: Expression of Rapeseed microsomal Lysophosphatidic Acid Acyltransferase Isozymes Enhances Seed Oil Content in Arabidopsis. Plant Physiology 2010, 152:670-684.

39. Jain RK, Coffey M, Lai K, Kumar A, MacKenzie SL: Enhancement of seed oil content by expression of glycerol-3-phosphate acyltransferase genes. Biochemical Society Transactions 2000, 28:958-961.

40. Aghoram K, Wilson RF, Burton JW, Dewey RE: A mutation in a 3-Keto-AcylACP Synthase II Gene is associated with elevated Palmitic acid levels in Soybean seeds. Crop Science 2006, 46:2453-2459.
41. Knutzon DS, Gregory A, Thompson, Sharon E, Radke, William B, Johnson Knauf VC, kridlt JC: Modification of Brassica seed oil by antisense expression of a stearoyl-acyl carrier protein desaturase gene. Proc Natl Acad Sci 1992, 89:2624-2628.

42. Goepfert $\mathrm{S}$, Poirier $\mathrm{Y}$ : $\beta$-Oxidation in fatty acid degradation and beyond. Current Opinion in Plant Biology 2007, 10:245-251.

43. Gao S, Ouyang C, Wang S, Xu Y, Tang L, Chen F: Effects of salt stress on growth, antioxidant enzyme and phenylalanine ammonia-lyase activities in Jatropha curcas L. seedlings. Plant Soil Environ 2008, 54:374-381.

44. Xiong L, Zhu JK: Molecular and genetic aspects of plant responses to osmotic stress. Plant Cell and Environment 2002, 25:131-139.

45. Kumar S, Dhingra A, Daniell H: Plastid- Expressed Betaine Aldehyde Dehydrogenase Gene in Carrot Cultured Cells, Roots, and Leaves Confers Enhanced Salt Tolerance. Plant Physiology 2004, 136:2843-2854.

46. Wu W, Su Q, Xia XY, Wang Y, Luan YS, An L: The Suaeda liaotungensis kitag betaine aldehyde dehydrogenase gene improves salt tolerance of transgenic maize mediated with minimum linear length of DNA fragment. Euphytica 2008, 159:17-25.

47. Jia GX, Zhu ZQ, Chang FQ, Li YX: Transformation of tomato with the BADH gene from Atriplex improves salt tolerance. Plant Cell Rep 2002, 21:141-146.

48. Zhang FL, Niu B, Wang YC, Chen F, Wang SH, Xu Y, Jiang LD, Gao S, Wu J, Tang $L$, Jia YJ: A novel betaine aldehyde dehydrogenase gene from Jatropha curcas, encoding an enzyme implicated in adaptation to environmental stress. Plant Science 2008, 174:510-518.

49. Nuccio ML, Russell BL, Nolte KD, Rathinasabapathi B, Gage DA, Hanson AD: The endogenous choline supply limits glycine betaine synthesis in transgenic tobacco expressing choline monooxygenase. Plant Journal 1998, 16:487-496.

50. Huang J, Hirji R, Adam L, Rozwadowski KL, Hammerlindl JK, Keller WA, Selvaraj G: Genetic Engineering of Glycinebetaine Production toward Enhancing Stress Tolerance in Plants: Metabolic Limitations. Plant Physiology 2000, 122:747-756.

51. Rajagopal D, Agarwal P, Tyagi W, Singla-Pareek SL, Reddy MK, Sopory SK Pennisetum glaucum $\mathrm{Na}+/ \mathrm{H}+$ antiporter confers high level of salinity tolerance in transgenic Brassica juncea. Mol Breeding 2007, 19:137-151.

52. Garg AK, Kim JK, Owens TG, Ranwala AP, Choi YD, Kochian LV, Wu RJ: Trehalose accumulation in rice plants confers high tolerance levels to different abiotic stresses. Proc Natl Acad Sci 2002, 99:15898-15903.

53. Terol J, Conesa A, Colmenero JM, Cercos M, Tadeo T, Agustí J, Alós E, Andres F, Soler G, Brumos J, Iglesias DJ, Götz S, Legaz F, Argout X, Courtois B, Ollitrault P, Dossat C, Wincker P, Morillon R, Talon M: Analysis of 13000 unique Citrus clusters associated with fruit quality, production and salinity tolerance. BMC Genomics 2007, 8:31.

54. Ho CL, Kwan YY, Choi MC, Tee SS, Ng WH, Lim KA, Lee YP, Ooi SE, Lee WW, Tee JM, Tan SH, Kulaveerasingam H, Alwee SS, Abdullah MO: Analysis and functional annotation of expressed sequence tags(ESTs) from multiple tissues of oil palm (Elaeis guineensis Jacq). BMC Genomics 2007, 8:381.

55. Yoshida S, Ishida JK, Kamal NM, Ali AM, Namba S, Shirasu K: A full-length enriched cDNA library and expressed sequence tag analysis of the parasitic weed, Striga hermonthica. BMC Plant Biology 2010, 10:55.

56. Fukuoka H, Yamaguchi $H$, Nunome T, Negoro S, Miyatake K, Ohyama A: Accumulation, functional annotation, and comparative analysis of expressed sequence tags in eggplant (Solanum melongena L.), the third pole of the genus Solanum species after tomato and potato. Gene 2010, 450:76-84.

57. Nanjo T, Sakurai T, Totoki Y, Toyoda A, Nishiguchi M, Kado T, Igasaki T, Futamura N, Seki M, Sakaki Y, Shinozaki K, Shinohara K: Functional annotation of 19,841 Populus nigra full-length enriched cDNA clones. BMC Genomics 2007, 8:448.

58. O'Hara P, Slabas AR, Fawcett T: Fatty Acid and Lipid Biosynthetic Genes Are Expressed at Constant Molar Ratios But Different Absolute Levels during Embryogenesis. Plant Physiology 2002, 129:310-320.

59. Patanjali SR, Parimoo S, Weissman SM: Construction of a uniformabundance (normalized) cDNA library. Proc Natl Acad Sci 1991, 88:1943-1947.

60. Soares MB, Bonaldo MF, Jelene $\mathrm{P}$, Su L, Lawton $\mathrm{L}$, Efstratiadis $A$ : Construction and characterization of a normalized cDNA library. Proc Natl Acad Sci 1994, 91:9228-9232.

61. National Centre for Biotechnology Information BLAST. [http://blast.ncbi. nlm.nih.gov/Blast.cgi]. 
62. Ewing $B$, Hillier $L$, Wendl MC, Green P: Base-calling of automated sequencer traces using phred. I. Accuracy assessment. Genome Res 1998, 8:175-185.

63. Huang X, Madan A: CAP3: A DNA sequence assembly program. Genome Res 1999, 9:868-877.

64. ClustalW2 Program. [http://www.ebi.ac.uk/Tools/clustalw2/index.html].

65. Open Reading Frame (ORF) Finder. [http://www.ncbi.nlm.nih.gov/projects/ gorf].

66. The Arabidopsis Information Resource. [http://www.arabidopsis.org].

doi:10.1186/1471-2164-11-606

Cite this article as: Natarajan et al:: Gene discovery from Jatropha curcas by sequencing of ESTs from normalized and full-length enriched CDNA library from developing seeds. BMC Genomics 2010 11:606.

Submit your next manuscript to BioMed Central and take full advantage of:

- Convenient online submission

- Thorough peer review

- No space constraints or color figure charges

- Immediate publication on acceptance

- Inclusion in PubMed, CAS, Scopus and Google Scholar

- Research which is freely available for redistribution

Submit your manuscript at www.biomedcentral.com/submit 